\title{
ANALISIS KONTRASTIF BAHASA INDONESIA, JAWA, DAN BANJAR SEBAGAI DASAR PENYUSUNAN MODEL PEMBELAJARAN BAHASA INDONESIA PERMULAAN
}

\author{
Suhardi dan Joko Santoso \\ Fakultas Bahasa dan Seni Universitas Negeri Yogyakarta \\ email: suhardiuny@yahoo.com
}

\begin{abstract}
This study aims to identify differences and similarities among the Indonesian, Banjarnese, and Javanese languages as a basis for designing a model for Indonesian learning for beginners. Field studies were conducted in Yogyakarta Special Territory where Javanese is used and in South Kalimantan where Banjarnese is used. The data were collected through interviews, observations, and listening and were analyzed using the contrastive-synchronic technique. The findings show that similarities among the three language lie in the levels of vocabulary, phrase structure, and clause/ sentence structure. In the level of vocabulary, there are similarities in phonological and morphological aspects. In the level of phrase structure, there is a similarity in the head-modifier structure. In the level of clause or sentence, there are similar structures of S-P, S-P-O/Com, and S-P-Adv, showing that the three languages belonging to the group with the S-V-O or S-P-O pattern.
\end{abstract}

Keywords: contrastive analysis, Indonesian language, Javanese language, Banjarnese language

\section{PENDAHULUAN}

Bangsa Indonesia adalah bangsa yang bersifat majemuk. Bangsa Indonesia terdiri dari berbagai suku dan etnik yang tersebar di seluruh wilayah Negara Kesatuan Republik Indonesia (NKRI). Tiap-tiap suku memiliki adat, budaya, dan bahasa yang berbeda. Dalam hal kekayaan bahasanya, menurut Peta Bahasa Nasional, jumlah bahasa daerah di Indonesia lebih dari 450 buah, belum termasuk bahasa-bahasa yang ada di Papua yang menurut perhitungan terakhir sekitar 350 buah. Bahasa-bahasa lokal tersebut ditengarai makin terkikis dari waktu ke waktu. Padahal, sesuai amanat UUD 1945, bahasa daerah itu perlu dijaga kelestariannya. Selain bahasa daerah, ada bahasa Indonesia yang digunakan secara nasional dan ditetapkan sebagai bahasa pengan- tar di sekolah-sekolah (UU Pendidikan, No. 20 Tahun 2003).

Ciri-ciri kebahasaan antara bahasa Indonesia dan bahasa daerah dimungkinkan berbeda, demikian pula ciri kebahasaan bahasa daerah satu dengan yang lain. Dalam hal pembelajaran bahasa, perbedaan ciri-ciri kebahasaan baik antar-bahasa daerah maupun bahasa daerah dan bahasa Indonesia menyulitkan guru dalam pembelajaran bahasa. Padahal, bahasa Indonesia sebagai bahasa pengantar di sekolah idealnya perlu dikuasai dengan baik oleh siswa. Terganggunya kondisi tersebut akan menghambat penyerapan semua mata pelajaran di sekolah. Yang menjadi masalah, oleh karena bahasa Indonesia harus diajarkan dengan bahasa pengantar bahasa Indonesia, siswa yang bahasa pertamanya bahasa daerah harus bela- 
jar dua kali, pertama memahami bahasa pengantarnya dan kedua belajar mata pelajaran bahasa Indonesia. Hal itu menyulitkan siswa, terutama siswa di daerah pinggiran dan pedalaman.

Di pihak lain, pada sekolah perkotaan ditengarai bahasa pertama siswa adalah bahasa Indonesia dan bahasa daerah (lokal) menjadi bahasa kedua (Suyata, 2007). Pembelajaran bahasa lokal tersebut kemudian menjadi mata pelajaran muatan lokal di sekolah. Selama ini, pembelajaran bahasa sebagai muatan lokal ditengarai menjadi hal yang menyulitkan siswa. Tampaknya, model pembelajaran berbasis bahasa dan budaya Indonesia dapat digunakan sebagai dasar untuk mengawali pembelajaran muatan lokal tersebut. Bahasa dan budaya adalah sesuatu yang tidak terpisahkan sebab bahasa adalah hasil budaya itu sendiri. Analisis kontrastif antarbahasa bermuara pada pembelajaran bahasa, budaya, dan kultur yang mendasari kebervariasian yang ada di Indonesia. Model pembelajaran bahasa Indonesia berbasis bahasa daerah dapat diperkenalkan pada guru, calon guru, atau masyarakat luas untuk mengurangi permasalahan yang ada.

Banyak model pengembangan pembelajaran yang telah dikemukakan oleh para ahli, baik melalui penelitian maupun kajian konseptual. Namun, tatkala model-model itu diterapkan oleh para guru di sekolah, seringkali hasilnya kurang efektif dan adaptabel. Hal itu disebabkan oleh kurang memadainya model atau pendekatan penelitian yang dipakai. Oleh karena itu, berdasarkan hasil analisis kontrastif diharapkan diperoleh model pembelajaran bahasa Indonesia berbasis bahasa daerah dan kultur untuk optimalisasi implementasi kurikulum di sekolah.

Secara spesifik, kajian ini bertujuan untuk (i) mengidentifikasi karakteristik kebahasaan yang dimiliki oleh bahasa Indonesia, Jawa, dan Banjar, (ii) membandingkan karakteristik kebahasaan tersebut secara sinkronis, dan (iii) menemukan kekhasan masing-masing bahasa dan kesamaannya.

Hasil kajian ini bermanfaat bagi guru, calon guru, diknas, dan masyarakat luas. Bagi guru dan calon guru, hasil kajian ini bermanfaat sebagai konsep dasar dalam merancang dan menyusun model pembelajaran bahasa Indonesia sebagai bahasa kedua (B-2), khususnya bagi sekolah-sekolah yang bahasa pertama (B-1) siswanya bahasa Jawa atau bahasa Banjar. Sebaliknya, hasil kajian ini juga bermanfaat sebagai dasar penyusunan model pembelaaran bahasa Jawa atau bahasa Banjar bagi siswa yang bahasa pertamanya bahasa Indonesia. Bagi diknas, hasil kajian ini memberikan manfaat bagi peningkatan mutu pendidikan di Indonesia secara keseluruhan. Bagi masyarakat Indonesia, hasil kajian ini bermanfaat sebagai sarana dalam upaya memperkokoh persatuan dan kesatuan bangsa.

Pada pasal 30 Undang-Undang Dasar 1945 disebutkan bahwa bahasa Indonesia adalah bahasa negara. Selanjutnya, bahasa Indonesia juga disebut sebagai bahasa nasional, bahasa administrasi negara, dan ditetapkan sebagai bahasa pengantar di sekolah-sekolah. Penetapan bahasa Indonesia sebagai bahasa pengantar dalam proses pembelajaran di semua jenjang pendidikan antara lain tertuang dalam UndangUndang Sisdiknas, Pasal 33 Ayat 1 Nomor 20 Tahun 2003. Di samping itu, ada ketentuan tambahan yang terkait dengan penggunaan bahasa daerah sebagai bahasa pengantar dalam proses pembelajaran. Sehubungan dengan itu, disebutkan bahwa bagi daerah-daerah yang masih kesulitan menggunakan bahasa Indonesia sebagai bahasa pengantar masih diperbolehkan menggunakan bahasa daerah. Ketentuan terse- 
but mengisyaratkan bahwa di daerah tertentu bahasa Indonesia belum bisa digunakan sebagai bahasa pengantar dalam pembelajaran di sekolah. Artinya, siswa belum memiliki kompetensi yang memadai untuk menggunakan bahasa Indonesia, baik secara pasif maupun aktif, sehingga dalam pembelajaran masih harus digunakan bahasa daerah sebagai bahasa pengantar.

Penetapan fungsi dan peran bahasa Indonesia seperti dikemukakan di atas memiliki konsekuensi bagi masyarakat Indonesia pada umumnya dan dunia pendidikan pada khususnya. Di satu sisi, masyarakat Indonesia dituntut agar bisa berbahasa Indonesia secara aktif dalam komunikasi seharihari, baik pada skala regional maupun nasional. Di sisi lain, dalam dunia pendidikan, penguasaan bahasa Indonesia menjadi hal yang sangat penting mengingat proses pembelajaran untuk semua mata pelajaran diselenggarakan dengan menggunakan bahasa Indonesia. Di samping dituntut untuk belajar berbahasa Indonesia, siswa juga dituntut untuk mempelajari semua mata pelajaran dengan bahasa Indonesia. Dengan demikian, baik atau buruknya kualitas pendidikan juga ditentukan oleh baik atau buruknya penguasaan bahasa Indonesia.

Telah diketahui bersama bahwa hasil Ujian Nasional th 2006, 2007, 2008, 2009, dan 2010 untuk semua mata pelajaran yang di-UNAS-kan belum membuahkan hasil seperti yang diharapkan, meski nilai rata-rata telah di atas batas kelulusan. Lebih memprihatinkan lagi, apabila memperhatikan hasil UNAS mata pelajaran Bahasa Indonesia seperti dikemukakan pada tabel 1 .

Tabel 1 menunjukkan bahwa hasil ujian nasional Bahasa Indonesia selama empat/lima tahun tersebut belum baik dan bahkan semakin menurun, kecuali nilai rata-rata untuk jenjang SMP/MTs. tahun ajaran 2009 dan 2010 mengalami sedikit kenaikan. Karena penguasaan bahasa Indonesia merupakan prasyarat bagi penggunaan bahasa Indonesia dalam penguasaan ilmu lain, kondisi seperti itu mengisyaratkan bahwa hasil ujian nasional mata pelajaran lain pun menurun, sementara itu standar kelulusan semakin naik.

Selain sebagai bahasa pengantar di sekolah, sebelum bahasa Indonesia dapat digunakan, bahasa daerah juga mengemban fungsi sebagai sarana pengembang budaya nasional di samping sebagai bagian dari budaya itu sendiri. Oleh karena itu, dalam kurikulum pendidikan, mata pelajaran bahasa daerah pada umumnya diberikan kepada siswa sebagai muatan lokal yang salah satu tujuannya ialah untuk melestarikan budaya lokal sebagai bagian budaya nasional.

Studi kekerabatan bahasa Austronesia telah dilakukan oleh banyak ahli. Salah satu studi kekerabatan itu dilakukan oleh Blust. Dalam studi kekerabatan, Blust menggunakan metode kualitatif yang disebut exclusively shared linguistics features. Oleh karena metode ini mengacu pada inovasi bersama yang

Tabel 1 Rerata Hasil Ujian Nasional Mata Pelajaran Bahasa Indonesia

\begin{tabular}{ccccccc}
\hline No. & Jenjang Sekolah & \multicolumn{5}{c}{ Tahun } \\
& & 2006 & 2007 & 2008 & 2009 & 2010 \\
1 & SMP/MTs. & 7,46 & 7,39 & 7.00 & 7.35 & 7.47 \\
2 & SMA/MA & 7,52 & 7,19 & 7,03 & 6,79 & - \\
\hline
\end{tabular}

Data : BSNP dan Puspendik 2006, 2007, 2008, 2009, 2010 
terjadi pada bahasa-bahasa, Crowley (1997) menamakannya sebagai shared innovation. Dengan metode ini pula, Blust (melalui Tyron, 1998) menyusun kekerabatan bahasa Austronesia sebagai berikut.

Induk bahasa Austronesia pecah menjadi dua cabang primer, yaitu kelompok Formosa dan Melayu Polinesia. Jika diteruskan, cabang yang disebut terakhir dapat dibagi lagi atas dua cabang utama, yaitu Melayu Polinesia Barat dan Melayu Polinesia Timur-Tengah. Selanjutnya rumpun Melayu Polinesia Timur-Tengah juga dibedakan atas Melayu Polinesia Tengah dan Timur. Bahasa Jawa dan bahasa Banjar termasuk kelompok Melayu Polinesia Barat. Bahasa Melayu sendiri termasuk kelompok Austronesia Barat. Dengan demikian, bahasa Indonesia yang merupakan hasil perkembangan bahasa Melayu juga termasuk kelompok Austronesia Barat. Jadi, bahasa Jawa, bahasa Banjar, dan bahasa Indonesia termasuk bahasa serumpun.

Menurut Tyron (dalam Bellwood, 1998), keluarga bahasa Austronesia tersebar paling luas di antara keluargakeluarga lain di dunia, yaitu dari Easter Island sampai Pulau Madagaskar. Saat ini bahasa Austronesia digunakan secara luas oleh penutur bahasa di Indonesia, Malaysia, Filipina, dan Madagaskar; bahkan juga digunakan oleh sebagian masyarakat Taiwan, Singapura, Vietnam, Myanmar, dan Kamboja.

Terkait dengan ciri kebahasaan, bahasa Jawa mempunyai karakteristik yang berbeda dengan bahasa Indonesia (Melayu). Di antaranya, di dalam bahasa Indonesia dikenal bentuk kami dan kita, sedangkan bahasa Jawa tidak memiliki bentuk padanannya (Suyata, 2007). Selanjutnya, bahasa Banjar adalah salah satu bahasa yang digunakan di wilayah Kalimantan Selatan. Bahasa Banjar tergolong rumpun bahasa Austronesia
Barat, termasuk pula di dalamnya bahasa Melayu (Indonesia). Kondisi tersebut mengisyaratkan adanya kedekatan antara bahasa Melayu (Indonesia) dan bahasa Banjar.

Menurut Fudiat (1981) ada persamaan yang cukup besar antara bahasa Banjar, bahasa Indonesia, dan Jawa. Segi-segi kesejarahan mengindikasikan adanya pengaruh bahasa Melayu (sekarang bahasa Indonesia), Jawa, dan Dayak terhadap bahasa Banjar. Selanjutnya Fudiat mengatakan, sejak lama kerajaan Banjar di bawah kekuasaan kerajaan di Jawa, yaitu Majapahit dan Demak. Pengaruh bahasa Jawa terhadap bahasa Banjar cukup kuat yang ditandai oleh banyaknya kata pinjaman dari bahasa Jawa.

Berdasarkan variasi pengucapan dalam kosakata yang digunakan oleh suku Banjar, bahasa Banjar dikelompokkan menjadi dua dialek, yakni dialek Banjar Kuala dan dialek Banjar Hulu Sungai atau Banjar Hulu (Hapip dalam Fudiat, 1984: 22). Dialek Banjar Kuala umumnya dipakai oleh penduduk "asli" di sekitar kota Banjarmasin, Martapura, dan Pelaihari, sedangkan dialek Banjar Hulu dipakai oleh penduduk di daerah Hulu Sungai pada umumnya, yaitu daerah-daerah Kabupaten Tapin, Hulu Sungai Selatang, Hulu Sungai Tengah, Hulu Sungai Utara, dan Tabalong. Variasi pengucapan terhadap fonem terstentu antara bahasa Banjar Kuala dan bahasa Banjar Hulu dapat diberikan contoh sebagai berikut.

$\begin{array}{lll}\begin{array}{l}\text { Banjar Kuala } \\ \text { koreng }\end{array} & \text { Banjar Hulu } \\ \text { gemet } & \text { gemit } & \text { 'borok' } \\ \text { sedang } & \text { sadang } & \text { 'selan' } \\ & & \text { 'sukup' } \\ \text { senang } & \text { sanang } & \text { 'senang' } \\ \text { ujan } & \text { hujan } & \text { 'hujan' } \\ \text { hangkut } & \text { angkut } & \text { 'angkut' }\end{array}$


Dalam contoh tersebut terlihat bahwa bahasa Banjar Kuala memiliki bunyi vokal [a, i, u, e, o], sedangkan bahasa Banjar Hulu hanya memiliki bunyi vokal [a, i, u]. Bunyi [כ] sering digunakan, tetapi sesungguhnya hal itu hanya alofon atau variasi dari fonem [a] (Hapip, 1997: iv).

Pohon ilmu Linguistik mengatakan bahwa Linguistik adalah bidang ilmu tentang bahasa, atau sering disebut dengan ilmu bahasa. Ada Linguistik Deskriptif yang berusaha melihat corak suatu bahasa. Dengan deskripsi pula, (Kridalaksana, 2007) corak suatu bahasa dapat digambarkan sampai pada aspek sekecil-kecilnya, seperti aspek fonologi, morfologi, sintaksis, dan semantisnya. Selain Linguistik Deskriptif, ada pula Linguistik Komparatif. Sesuai dengan namanya, bidang Linguistik tersebut bekerja dengan cara membandingkan antara deskripsi bahasa satu dan deskripsi bahasa yang lain. Cara kerja Linguistik Komparatif ada dua macam, yaitu melalui metode sinkronis dan metode diakronis. Metode sinkronis digunakan untuk membandingkan dua atau lebih bahasa dari kurun waktu yang sama, sementara metode diakronis digunakan untuk membandingkan dua atau lebih bahasa dari kurun waktu yang berbeda. Metode sinkronis memanfaatkan analisis kontrastif, sementara metode diakronis menerapkan analisis historis (Suyata, 1997).

Dalam perkembangannya, analisis kontrastif digunakan untuk pembelajaran bahasa, khususnya untuk pembelajaran bahasa kedua atau bahasa asing (Parera, 1998). Para penganut analisis kontrastif mempunyai beberapa asumsi dasar sebagai berikut.

a. Analisis kontrastif dapat digunakan untuk meramalkan kesalahan atau kesulitan siswa dalam mempelajari bahasa kedua. Adanya perbedaan antara bahasa pertama dan kedua akan memberikan kesulitan pada pembelajar dalam mempelajari bahasa kedua. Sebaliknya, adanya aspekaspek yang sama akan mempermudah pembelajar dalam mempelajari bahasa kedua.

b. Analisis kontrasftif dapat memberikan sumbangan dalam mengurangi proses interferensi dari bahasa pertama ke bahasa kedua (termasuk bahasa asing).

c. Dalam analisis kontrastif, ada dua istilah yang sering muncul, yaitu interferensi dan tranfer (Parera, 1998). Interferensi terjadi jika tingkah laku lama berpengaruh terhadap hal-hal baru yang sedang dipelajari. Dalam linguistik istilah itu digunakan untuk merunjuk ke interaksi berbahasa, seperti pinjaman linguistik dan alih kode yang terjadi sewaktu dua bahasa berkontak. Sementara itu, transfer menurut para psikolog tingkah laku, merujuk pada proses penggunaan pengalaman yang silam secara otomatis, tidak terkendali, dan bersifat bawah sadar, dalam usaha menjawab tantangan baru. Dalam hal ini dapat terjadi tranfer positif atau tranfer negatif. Tranfer negatif terjadi jika bentuk lama tidak terdapat pada situasi baru, sedangkan tranfer positif terjadi jika kebiasaan lama dan baru terdapat persamaan. Dalam belajar bahasa kedua, seorang pembelajar melakukan tranfer baik positif maupun negatif.

Selanjutnya, Parera menyarankan langkah-langkah analisis kontrastif sebagai berikut: (i) tempatkan satu deskripsi struktural bahasa-bahasa yang akan dibandingkan, (ii) rangkum dalam suatu ikhtisar yang terpadu semua kemungkinan pada setiap tataran analisis bahasa yang diteliti, dan (iii) bandingkan dua bahasa itu struktur demi struktur. Dari langkah itu ditemukan pola-pola yang sama dan yang berbeda. Dengan 
demikian, dapat diramalkan kemungkinan hambatan dalam pembelajaran bahasa-bahasa tersebut.

Ada dua istilah yang berdekatan dalam pembelajaran bahasa kedua, yaitu pembelajaran bahasa dan pemerolehan bahasa. Pembelajaran bahasa dilakukan secara sengaja dalam situasi formal, biasanya di kelas atau sekolah dengan bantuan guru, sementara pemerolehan dilakukan secara tidak sengaja dan dalam situasi nonformal. Dalam belajar bahasa ada teori tranfer dan interferensi, sedangkan dalam pemerolehan bahasa kedua ada teori identity hypotesis, input hypothesis, natural order hypothesis, monitor hypothesis, dan affective filter (Setiawati dan Kushatanti, 2007). Hipotesis tersebut memberikan petunjuk bagaimana seseorang memperoleh bahasa kedua.

\section{METODE}

Penelitian ini dilakukan dengan pendekatan research and development. Pendekatan ini digunakan dalam dua hal, yaitu kajian lapangan dan perumusan model pembelajaran. Data diperoleh melalui survei dengan beberapa teknik, yaitu wawancara, observasi, dan penyimakan. Analisis data dilakukan dengan analisis kontrastif-sinkronis dan hasil yang diperoleh berupa deskripsi kesamaan dan perbedaan aspek kebahasaan serta aspek budaya yang melatarbelakanginya. Hasil ini kemudian digunakan sebagai dasar perumusan model pembelajaran bahasa berbasis kultur.

Studi lapangan dilakukan di wilayah pemakaian bahasa Jawa, yaitu di Daerah Istimewa Yogyakarta, dan di wilayah pemakaian bahasa Banjar, yaitu di Kalimantan Selatan. Informan yang dilibatkan dalam studi lapangan ialah penutur asli bahasa Jawa dan penutur asli bahasa Banjar yang memenuhi kriteria yang telah ditetapkan: usia 30-50 tahun, sehat, dapat berbicara dengan jelas, mobilitas rendah, pendidikan minimal
SD, penduduk asli, dan bisa berbahasa Indonesia.

Instrumen yang digunakan berupa daftar tanyaan yang berkenaan dengan kosakata, struktur frasa, dan struktur klausa/kalimat. Daftar tanyaan kosakata terdiri atas 600 pertanyaan yang terkait dengan 16 medan leksikal (medan budaya). Daftar tanyaan frase berjumlah 100 yang aplikasinya dikemas dalam bentuk kalimat atau cerita dan daftar tanyaan kalimat berjumlah 100 yang aplikasinya berupa cerita atau dialog ringan.

\section{HASIL DAN PEMBAHASAN}

Kajian ini dilakukan melalui analisis kontrastif antara bahasa Indonesia, Banjar, dan Jawa. Hasilnya ialah deskripsi perbedaan dan kesamaan aspek kebahasaan antara bahasa Indonesia-Banjar, Indonesia-Jawa, dan Jawa-Banjar. Hasil kajian ini diharapkan dapat dimanfaatkan sebagai dasar penyusunan model pembelajaran bahasa, baik pembelajaran bahasa Indonesia, Banjar, maupun Jawa dengan mempertimbangkan pula aspek kultur atau budaya yang melatarbelakanginya.

Kajian ini direncanakan dan dilaksanakan dengan didasarkan pada asumsi bahwa antara bahasa Indonesia, Banjar, dan Jawa terdapat kesamaan-kesamaan unsur dan struktur kebahasaan. Kesamaan unsur dilihat melalui analisis kontrastif pada tataran kosakata, baik mengenai unsur fonologis (bunyi/ fonem) maupun unsur morfologisnya. Di samping itu, kesamaan struktur dilihat melalui analisis kontrastif pada tataran frasa dan klausa/kalimat. Asumsi itu dilandasi oleh hasil studi Linguistik Historis Komparatif yang mengungkapkan bahwa bahasa Indonesia dan Jawa merupakan satu kelompok, yaitu kelompok bahasa Austronesia Barat. Di samping itu, yang juga termasuk kelompok Austronesia Barat ialah bahasa-ba- 
hasa di Madagaskar, Malaysia, Filipina, dan di wilayah Indonesia bagian barat, seperti Sumatra, Kalimantan, Sulawesi, Jawa, dan NTB (Blust melalui Tyron, 1998). Dengan demikian, bahasa Indonesia (Melayu), Jawa, dan Banjar adalah bahasa-bahasa yang termasuk dalam kelompok bahasa Astronesia Barat. Pada umumnya, bahasa-bahasa yang berada dalam satu kelompokitu memiliki karakteristik yang relatif sama, walaupun dalam perkembangannya tercipta perbedaan-perbedaan.

Melalui kajian ini kesamaan unsur dan struktur kebahasaan antara bahasa Indonesia, Banjar, dan Jawa dapat dideskripsikan. Berdasarkan hasil analisis kontrastif dapat diketahui bahwa antara BI, Banjar, dan Jawa terdapat kesamaan atau kemiripan, baik mengenai aspek kosakata, fonologis, morfologis, maupun sintaktisnya. Kesamaan atau kemiripan itu dapat dikemukakian sebagai berikut.

\section{Perbedaan dan Kesamaan dalam Tat- aran Kosakata}

Pada tataran kosakata ditemukan korespondensi bunyi antara BI, Banjar, dan Jawa. Korespondensi ketiga bahasa itu menampakkan tingkat kesamaan atau kedekatan yang berbeda-beda. Sebagian data menunjukkan bahwa BI lebih mirip dengan $\mathrm{BB}$, tetapi sebagian data yang lain menampakkan bahwa BI lebih mirip dengan BJ.

$\begin{array}{cccc} & \text { BJ } & \text { BB } & \text { BI } \\ & \text { [ə] } & \text { [a] } & \text { [a] } \\ \text { genap } & \text { [gənəp] } & \text { [gənap] } & \text { [gənap] } \\ \text { enam } & \text { [ənəm] } & \text { [ənam] } & \text { [ənam] } \\ \text { ular } & \text { [ulər] } & \text { [?ulat] } & \text { [?ular] } \\ \text { eras } & \text { [dərəs] } & \text { [dəras] } & \text { [dəras] } \\ \text { pedas } & \text { [pədəs] } & \text { [pədas] } & \text { [pədas] }\end{array}$

Contoh data pada tabel di atas menunjukkan bahwa BI sama dengan BB, sedangkan keduanya memiliki kemiripan dengan BJ. Pasangan kata di dalam tabel itu menampakkan adanya korespondensi antara bunyi [ə] dalam BJ, bunyi [a] dalam BB, dan bunyi [a] dalam BI. Artinya, BB lebih mirip dengan BI daripada dengan BJ. Namun, pasangan kata dalam tabel berikut menampakkan gejala yang berbeda.

\begin{tabular}{|c|c|c|c|}
\hline & BJ & BB & BI \\
\hline & $\begin{array}{c}{[ə]} \\
\text { [galan] }\end{array}$ & [a] & $\begin{array}{l}\text { [ə] } \\
\end{array}$ \\
\hline $\begin{array}{c}\text { gelang } \\
\text { welut }\end{array}$ & $\begin{array}{l}\text { [galan] } \\
\text { [wolut] }\end{array}$ & $\begin{array}{l}\text { Lgalan] } \\
\text { [walut] }\end{array}$ & $\begin{array}{l}\text { [gəral)] } \\
\text { [bəlut] }\end{array}$ \\
\hline semut & [səmut] & [samut] & [səmut] \\
\hline bandeng & [bandən] & [bandan] & [bandən] \\
\hline embun & [?əmbun] & [?ambun] & [?əmbun \\
\hline
\end{tabular}

Pasangan kata di dalam tabel di atas menampakkan adanya korespondensi antara bunyi [ə] dalam BJ, bunyi [a] dalam BB, dan bunyi [ə] dalam BI. Artinya, BJ lebih mirip dengan BI daripada dengan BB. Sehubungan dengan tujuan penelitian ini, hasil analisis kontrastif yang menunjukkan adanya gejala semacam itu tetap dapat dimanfaatkan. Lebih lanjut dapat dilaporkan bahwa pada umumnya pasangan bunyi [ə] Indonesia-Jawa berkorespondensi dengan bunyi [a] dalam BB, sedangkan pasangan bunyi [a] dalam BI-Banjar hanya sedikit yang berkorespondensi dengan bunyi [ə] dalam BJ. Bunyi [ə] dalam BI banyak yang berkorespondensi dengan bunyi [a] dalam BB. Sekali lagi, adanya gejala semacam itu tetap dapat dimanfaatkan dalam penyusunan model pembelajaran bahasa kedua berbasis bahasa daerah.

Selanjutnya, dikemukakan korespondensi antara bunyi [w] dalam BJ, bunyi $[\mathrm{b}$ ] dalam $B B$, dan bunyi [b] dalam BI. Hal itu dapat dipahami lebih jelas melalui tabel berikut ini.

\begin{tabular}{|c|c|c|c|}
\hline & BJ & BB & BI \\
\hline & {$[\mathbf{w}]$} & [b] & [b] \\
\hline uban & [?uwan] & [?uban] & [?uban] \\
\hline belalang & [walan] & [b ə lalan] & [b ə lalan] \\
\hline belibis & [mliwIs] & [b ə libIs] & [b ə libIs] \\
\hline beringin & [w $\partial$ rin In] & [b ə rin In] & [b o rin In] \\
\hline
\end{tabular}


belut [w ə lUt] [b ə lUt] [b ə lUt] bungkus [wunkUs] [bunkUs] [bunkUs] cobek [cowèk] [cobèk] [cobèk]

Pasangan kata dalam tabel di atas menunjukkan bahwa bunyi [b] dalam BI dan Banjar berkorespondensi dengan bunyi [ə] dalam BJ. Korespondensi itu menampakkan bahwa ketiga bahasa itu termasuk bahasa-bahasa serumpun yang cukup dekat.

Hal lain yang dapat dilaporkan adalah adanya korespondensi antara bunyi [e] dalam BJ, diftong $\left[\mathrm{a}^{\mathrm{y}}\right]$ dalam $\mathrm{BB}$, dan diftong $\left[\mathrm{a}^{\mathrm{y}}\right]$ dalam BI. Hal itu tampak pada contoh berikut.

\begin{tabular}{|c|c|c|c|}
\hline & $\begin{array}{l}\text { BJ } \\
{[\mathbf{e}]}\end{array}$ & $\begin{array}{c}\mathbf{B B} \\
{\left[\mathbf{a}^{\mathbf{y}}\right]}\end{array}$ & $\begin{array}{c}\mathbf{B I} \\
{\left[\mathbf{a}^{\mathbf{y}}\right]}\end{array}$ \\
\hline rantai & [rante] & {$\left[\right.$ ranta $\left.^{\mathrm{y}}\right]$} & {$\left[\operatorname{ranta}^{\mathrm{y}}\right]$} \\
\hline petai & [pote] & {$\left[\right.$ pota $\left.^{\mathrm{y}}\right]$} & {$\left[\right.$ pota $\left.^{\mathrm{y}}\right]$} \\
\hline serai & [sore] & {$\left[\right.$ səra $^{\mathrm{y}}$ ] } & [sora $\left.{ }^{\mathrm{y}}\right]$ \\
\hline lantai & [lante] & {$\left[\right.$ lanta $\left.^{\mathrm{y}}\right]$} & [lanta $\left.{ }^{\mathrm{y}}\right]$ \\
\hline tapai & [tape] & {$\left[\operatorname{tapa}^{\mathrm{y}}\right]$} & {$\left[\operatorname{tapa}^{\mathrm{y}}\right]$} \\
\hline balai & [bale] & [bala $\left.{ }^{\mathrm{y}}\right]$ & [bala $\left.{ }^{\mathrm{y}}\right]$ \\
\hline
\end{tabular}

Tabel di atas menunjukkan bahwa bunyi-bunyi [e] dalam BJ secara konsisten berkorespondensi dengan bunyi $\left[\mathrm{a}^{\mathrm{y}}\right]$ dalam BB dan BI. Selain itu, dapat diketahui pula bahwa kata-kata dalam BB tersebut sama persis dengan kosakata dalam BI. Tampaknya pengaruh BI, dulu disebut bahasa Melayu, terhadap BB cukup kuat.

Analisis kontrastif BJ-Banjar-Indonesia juga menunjukan bahwa telah terjadi korespondensi antara bunyi [o] dalam BJ, bunyi diftong $\left[\mathrm{a}^{\mathrm{w}}\right]$ dalam BB, dan bunyi diftong $\left[\mathrm{a}^{\mathrm{w}}\right]$ dalam BI. Hal itu tampak pada tabel berikut.

$\begin{array}{cccc} & \text { BJ } & \text { BB } & \text { BI } \\ \text { bangau } & {[\mathbf{0}]} & {\left[\mathbf{a}^{\mathbf{w}}\right]} & {\left[\mathbf{a}^{\mathbf{w}}\right]} \\ \text { pulau }] & {[\mathrm{bulo}]} & {\left[\mathrm{bana}^{\mathrm{w}}\right]} & {\left[\mathrm{bana}^{\mathrm{w}}\right]} \\ \text { kerbau } & {[\mathrm{k} \text { ə bo }]} & {\left[\mathrm{k} \text { ə } \mathrm{rba}^{\mathrm{w}}\right]} & {\left[\mathrm{pula}^{\mathrm{w}}\right]} \\ {\left[\mathrm{k} \text { ə } \mathrm{rba}^{\mathrm{w}}\right]}\end{array}$

Pada tabel di atas terlihat pasangan kata BJ-Banjar-Indonesia yang me- nampakkan korespondensi bunyi yang berulang sama. Bunyi [o] dalam BJ menjadi diftong $\left[\mathrm{a}^{\mathrm{w}}\right]$ dalam $\mathrm{BB}$ dan BI. Tampaknya, hal tersebut menunjukkan bahwa penutur BJ tidak menyukai bunyi vokal rangkap, sehingga bunyi itu disederhanakan menjadi bunyi monoftong [o] dalam BJ.

Bunyi [o] atau [0] dalam BJ menjadi bunyi [u] dalam BB, tetapi bunyi [o] dalam BJ bisa menjadi bunyi [o] atau [u] dalam BI. Hal itu tampak pada contoh berikut ini.

\begin{tabular}{|c|c|c|c|}
\hline & BJ & BB & BI \\
\hline & [o] atau [0 ] & [u] & {$[\mathbf{o}],[0],[\mathbf{u}]$} \\
\hline terong & {$\left[\begin{array}{lll}\text { ter } 0 & \text { n] }\end{array}\right.$} & [tarU n] & {$\left[\begin{array}{lll}\text { ter } 0 & \mathbf{n}\end{array}\right]$} \\
\hline aos & {$\left[\begin{array}{lll}\text { la } & 0 & s\end{array}\right]$} & [laus] & {$\left[\begin{array}{lll}\text { la } 0 & s\end{array}\right]$} \\
\hline sawo & [sawo] & [sawu] & [sawo] \\
\hline rumah & [?omah] & [rumah] & [rumah] \\
\hline jarum & {$\left[\begin{array}{lll}\mathrm{d} & \mathrm{m}\end{array}\right]$} & [jarUm] & [jarUm] \\
\hline
\end{tabular}

Pasangan kata pada tabel di atas dapat menunjukkan bahwa bunyi [o] atau [O] dalam BJ berkorespondensi secara teratur dengan bunyi [u] dalam BB. Bunyi [O] dalam BJ menjadi bunyi yang sama [O] dalam bahasa Indoensia. Namun, bunyi [o] dalam BJ bisa menjadi bunyi [o] atau [u] dalam BI.

Selain itu, data juga menunjukkan bahwa bunyi [r] dalam BJ berkorespondensi dengan bunyi [d] dalam BB, sedangkan dalam BI bisa menjadi [d] atau tetap [r]. Hal itu tampak pada contoh berikut.

\begin{tabular}{|c|c|c|c|}
\hline & $\begin{array}{c}\text { BJ } \\
{[\mathbf{r}],[\mathbf{d}]}\end{array}$ & $\begin{array}{c}\mathbf{B B} \\
{[\mathbf{r}],[\mathbf{d}]}\end{array}$ & $\begin{array}{c}\text { BI } \\
{[\mathbf{r}],[\mathbf{d}]}\end{array}$ \\
\hline udang & [?uran] & [?udan] & [?udan] \\
\hline & [?urat] & [?udat] & [?urat] \\
\hline$d a h$ & [rai] & [dahi] & [udim] \\
\hline jarur & [dom] & [jarum] & [jarum] \\
\hline
\end{tabular}

Tabel tersebut menunjukkan telah terjadi korespondensi antara bunyi [r] dalam BJ dan bunyi [d] dalam BB. Sebaliknya, juga terjadi korespondensi antara bunyi [d] dalam BJ dan bunyi [r] dalam BB. Demikian pula, bunyi [r] 
dalam BJ bisa menjadi bunyi [r] atau [d] dalam BI, sebaliknya bunyi [d] dalam BJ bisa menjadi bunyi [r] dalam BI.

Selain kosakata yang kontras, terdapat pula bentuk-bentuk kosakata yang sama antara BJ, BB, dan BI. Berikut adalah contoh-contoh yang dapat disebutkan.

$\begin{array}{lll}\text { BJ } & \text { BB } & \text { BI } \\ \text { kayu } & \text { kayu } & \text { kayu } \\ \text { panas } & \text { panas } & \text { panas } \\ \text { jagung } & \text { jagung } & \text { jagung } \\ \text { kampung } & \text { kampung } & \text { kampung } \\ \text { tahun } & \text { tahun } & \text { tahun } \\ \text { minggu } & \text { minggu } & \text { minggu } \\ \text { kukus } & \text { kukus } & \text { kukus }\end{array}$

\begin{tabular}{|c|c|}
\hline Jenis Frasa & BJ \\
\hline F. Nomina & $\begin{array}{l}\text { iwak loh } \\
\text { tanduran pari } \\
\text { banyu udan }\end{array}$ \\
\hline F. Verba & $\begin{array}{l}\text { mbakar tela } \\
\text { nggodok jagung } \\
\text { nəgor kayu }\end{array}$ \\
\hline F. Nomina Posesif & $\begin{array}{l}\text { adimu } \\
\text { bapake } \\
\text { omahku }\end{array}$ \\
\hline F. Bilangan & $\begin{array}{l}\text { rong wulan } \\
\text { telung tahun } \\
\text { sedina }\end{array}$ \\
\hline F. Preposisi & $\begin{array}{l}\text { neng pante } \\
\text { seko ngalas } \\
\text { nang pasar }\end{array}$ \\
\hline F. Adverbia & $\begin{array}{l}\text { sing kuwi } \\
\text { sing endi }\end{array}$ \\
\hline F.Adjektiva & $\begin{array}{l}\text { lara nemen } \\
\text { apik banget } \\
\text { kurang sitik }\end{array}$ \\
\hline
\end{tabular}

Pada tabel di atas, dapat dilihat adanya kesejajaran antara struktur frasa BJ, BB, dan BI. Baik frasa nomina, verba, adjektiva, bilangan, preposisi, posesif, maupun adverbia memiliki struktur yang sama, yaitu Diterangkan - Menerangkan. Kenyataan tersebut memperkuat penemuan Blust (1994) yang terkait dengan subgrouping bahasa Aus-
Bentuk-bentuk yang sama persis antara BJ, BB, dan BI berjumlah cukup banyak. Kondisi tersebut pantas diduga disebabkan oleh adanya pengaruh bahasa pada masa kejayaan pemerintahan Majapahit dan Sriwijaya.

\section{Perbedaan dan Kesamaan dalam Tat- aran Frasa}

Pada tataran frasa, ada kesamaan antara struktur frasa BJ, BB, dan BI. Frasa ketiga bahasa itu memiliki struktur DM. Hal itu tampak pada contoh berikut.

\begin{tabular}{ll}
\multicolumn{1}{c}{$\quad$ BB } & \multicolumn{1}{c}{$\mathbf{D}-\mathbf{M}$} \\
iwak səgara & \multicolumn{1}{c}{$\mathbf{D}-\mathbf{M}$} \\
tanaman banih & ikan laut \\
banyu hujan & air hujan padi \\
mambanam gumbili & membakar ketela \\
manjarang jagung & merebus jagung \\
manabang kayu & menebang pohon \\
ading nyawa & adikmu \\
abah inya & ayahnya \\
rumah unda & Rumahku \\
dua bulan & dua bulan \\
tiga tahun & tiga tahun \\
sehari & sehari \\
ka pantai & ke pantai \\
dari pahuman & dari sawah \\
ke pasar & ke pasar \\
nang itu & yang itu \\
nang mana & yang mana \\
sakit banar & sakit sekali \\
bagus banar & bagus sekali \\
kurang sedikit & kurang sedikit \\
\end{tabular}

tronesia. Blust menemukan bahwa BJ, Melayu, dan Banjar termasuk kelompok Bahasa Austronesia Barat. Subgrouping dilakukan dengan metode Exlusively Shared Linguistics Features yang memperhitungkan sifat-sifat linguistik bahasabahasa yang diteliti. Metode Blust juga dikenal sebagai metode kualitatif dalam subgrouping (Bellwood, 1998). Kondisi 
tersebut memperlihatkan bukti-bukti adanya kesamaan sifat-sifat linguistik antara BJ, Melayu (Indonesia), dan Banjar.

\section{Perbedaan dan Kesamaan dalam Tat- aran Klausa/Kalimat}

Data menunjukkan bahwa pada tataran klausa/kalimat, struktur klausa/ kalimat BJ, BB, dan BI adalah sama. Bukti-bukti ke arah itu dapat diamati pada contoh berikut.

\section{BJ Aku dilahirke na kampung

$\mathrm{S} P \mathrm{~K}$ \\ BB Aku dipanakkan di kampung

$\mathrm{S} \quad \mathrm{P} \quad \mathrm{K}$ \\ BI Saya dilahirkan di kampung $\mathrm{S} \quad \mathrm{P} \quad \mathrm{K}$ \\ BJ Ibuku dodolan sayur \\ BB Mama unda bejualan sayur \\ BI Ibu saya bejualan sayur $S$ P PEL \\ BJ $\quad \frac{\text { Angine adəm bangat }}{\mathrm{S}} \frac{\mathrm{P}}{\mathrm{P}}$ \\ BB $\frac{\text { Angina dingin banar }}{\mathrm{S}} \frac{\mathrm{P}}{\mathrm{P}}$ \\ BI Udaranya dingin sekali}

Kesejajaran strtuktur klausa/kalimat BJ, BB, dan BI tampak dari susunan Subjek-Predikat-Objek/PelengkapnyaKeterangan. Hal tersebut sesuai dengan yang dikatakan ahli-ahli terdahulu, seperti Blust (1994) dan Bellwood (1995). Dikatakannya bahwa bahasa Astronesia Barat, seperti Jawa dan Banjar bersusunan V-O atau S-P-O dan bahasa Austronensia Timur bersusunan $\mathrm{O}-\mathrm{V}$ atau SO-P.

Implementasi dalam Pembelajaran Bahasa Indonesia Permulaan

Dalam dunia pendidikan, khususnya pembelajaran bahasa, terutama pada tingkat pemula, kesamaan kosakata dan struktur antara B-1 (bahasa pertama) dan B-2 (bahasa kedua) akan memudah- kan peserta didik dalam mempelajari bahasa kedua. Jadi, peserta didik yang berbahasa pertama BJ akan lebih mudah dalam mempelajari BI atau BB sebagai bahasa kedua; peserta didik yang berbahasa pertama BB akan lebih mudah dalam mempelajari BI atau BJ sebagai bahasa kedua; peserta didik yang berbahasa pertama BI akan lebih mudah dalam mempelajari BJ atau BB sebagai bahasa kedua; atau sebaliknya.

Bahasa daerah (BJ atau BB) sudah dikenal siswa sejak mereka lahir, karena bahasa itu merupakan bahasa pertama (B-1) atau bahasa ibu mereka. Kontras antara B-1, yang sudah mereka kenal, dan bahasa kedua (B-2), akan memudahkan mereka belajar B-2, khususnya pada SD permulaan. Dalam pembelajaran kosakata, misalnya, pertama-tama dapat diperkenalkan kosakata B-1 dan padanannya dalam B-2. Guru dapat memilih sejumlah kosakata yang sama atau mirip untuk digunakan sebagai materi pembelajarannya.

Di samping itu, belajar bahasa tidak terlepas dari belajar budaya, misalnya, belajar bahasa Jawa, bahasa Banjar, dan Indonesia juga tidak lepas dari budaya Jawa, budaya Banjar, dan budaya Indonesia. Dengan demikian, belajar bahasa dapat dilakukan dengan titik tolak bahasa dan budaya. Misalnya, di samping mirip atau sama, kosakata yang akan digunakan sebagai materi pembelajaran dipilih berdasarkan kesamaan latar belakang budaya siswa: pekerjaan, tempat tinggal, kekerabatan, kebiasaan hidup, pranata sosial, kepercayaan, penamaan benda-benda di sekitarnya, dan sebagainya.

Karena BI, BJ, dab BB memiliki kesamaan struktur frasa, yaitu ketiganya berstruktur D-M, pembelajaran yang terkait dengan keterampilan pemakaian kelompok kata akan menjadi mudah. Artinya, siswa tidak mengalami kesulitan dan kesalahan dalam me- 
nyusun kelompok kata. Dalam hal ini, tentu saja, materi pembelajaran sebaiknya tidak berkenaan dengan struktur frasa yang kebetulan berbeda.

Seperti dalam pembelajaran kosakata, pembelajaran struktur frasa juga dapat dilakukan dengan bertitik tolak pada kesamaan aspek budaya yang dekat dengan kehidupan siswa, sesuai dengan perkembangan usianya. Artinya, dalam pembelajaran struktur frasa, guru dapat memilih aspek budaya yang sama yang berkenaan dengan tema kehidupan yang sesuai dengan usia perkembangan siswa. Baru kemudian memilih frasa-frasa yang sama antara B-1 dan B-2 yang berkenaan dengan tema kehidupan siswa tersebut. Dengan demikian, siswa tidak akan mendapatkan kendala dalam pembelajaran.

Sama seperti halnya pembelajaran kelompok kata, pembelajaran kalimat dapat menggunakan model terjemahan kata per kata karena struktur kalimat ketiga bahasa itu tidak berbeda. Di samping itu, guru juga bisa memanfaatkan kesamaan aspek budaya. Dengan demikian, materi pembelajaran yang terkait dengan penguasaan kompetensi pengalimatan dapat dipilih atau ditentukan secara tematik. Tema-tema yang dipilih dan ditentukan tentu saja harus berkenaan dengan hal-hal yang sudah familier bagi siswa. Misalnya, sopan santun, gotong royong, kepedulian sosial, kejujuran, kepercayaan, tanggug jawab, ketangguhan, keberanian, percaya diri, kebersihan, kesehatan, dan sejenisnya adalah tema-tema yang dapat dipilih oleh guru.

\section{SIMPULAN}

Pada kajian ini dihasilkan deskripsi kemiripan dan kesamaan antara BI, BB, dan BJ. Kesamaan dan kemiripan ketiga bahasa itu berkenaan dengan aspek kebahasaan pada tataran kosakata, struktur frasa, dan struktur klausa/ kalimat. Pada tataran kosakata, ketiga bahasa itu menampakkan (i) kesamaan kata dan (ii) kemiripan kosakata yang ditandai oleh adanya korespondensi bunyi pembentuknya. Pada tataran frasa, ketiga bahasa menampakkan kesamaan struktur, yaitu berstruktur DiterangkanMenerangkan (DM). Pada tataran klausa/ kalimat, ketiga bahasa menampakkan struktur yang sama, baik pada klausa yang berstruktur S-P, S-P-O/PEL, maupun S-P-K. Artinya, ketiga bahasa itu termasuk kelompok bahasa yang berpola S-V-O atau S-P-O.

Karena BI, BJ, dan BB memiliki banyak kesamaan dan kemiripan, baik aspek kosakata maupun struktur sintaksisnya (struktur frasa, klausa, dan kalimat), pembelajaran bahasa dapat dilaksanakan dengan memanfaatkan kesamaan atau kemiripan itu, khususnya pada tahap permulaan. Aspek kebahasaan yang dipilih sebaiknya berkenaan dengan kesamaan aspek budaya yang dimiliki siswa dan pembelajaran bersifat tematik yang telah familier bagi siswa, misalnya sopan santun, gotong royong, kepedulian sosial, kejujuran, kepercayaan, tanggug jawab, ketangguhan, keberanian, percaya diri, kebersihan, kesehatan, dan sejenisnya.

Berdasarkan hasil kajian ini disarankan kepada semua pihak yang bertanggung jawab terhadap pembelajaran bahasa Indonesia, Jawa, atau Banjar untuk mempertimbangkan model pembelajarannya dengan memanfaatkan kesamaan dan kemiripan yang dimiliki oleh ketiga bahasa itu, baik mengenai kosakata, struktur frasa, maupun struktur klausa/kalimatnya. Paling tidak, kesamaan dan kemiripan aspek kebahasaan itu digunakan pada tingkat awal agar peserta didik tidak mengalami kesulitan mempelajari dan menguasai ketiga bahasa tersebut. 


\section{UCAPAN TERIMA KASIH}

Ucapan terima kasih disampaikan kepada Direktur P2M Jakarta yang telah memberikan kesempatan dan biaya untuk melakukan penelitian yang kemudian ditulis dalam artikel ini. Selain itu, terima kasih disampaikan pula kepada tim redaksi majalah Litera yang telah memberikan masukan untuk perbaikan artikel ini.

\section{DAFTAR PUSTAKA}

Adelaar, Alexsander. K. 1995. Borneo as Across-roads for Comparative Austronesian Linguistics dalam Bellwood The Austronesian: Historical and Comparative Perspective. Canberra: ANU Printing Service.

Bellwood, Petter dkk. 1998. The Austronesian: Historical and Comparative Perspective. Canberra: ANU Printing Service.

Budi Kusworo. 2006. "Pengendalian Mutu Pendidikan Dasar dan Menengah". Jurnal Puspendik Vol 3/ No.1.

Crowley, Terry. 1997. An Introduction to Historical Linguistics. Suva: Iniversity of Papua, New Guinea.

Dhanawati, Ni Made. 2002. "Variasi Dialektal Bahasa Bali di Daerah Transmigrasi Lampung Tengah". Disertasi. Universitas Gajahmada.

Fudiat, Suryadikara. 1981. "Bentuk Kata-kata Pungut Bahasa Jawa dalam Bahasa Banjar". Penelitian : ILDEP.

Gibson, Joseph. 1998. “Education and Plutalism" In Thomas . Labelle (ed) Education and Development: Latin America and the Caribbean. Angelos: Latin American Center, UCLA.
Hapip, Abdul Djebar. 1997. Kamus Bahasa Banjar-Indonesia, Edisi III 1997. Banjarmasin: PT Grafika Wangi, Kalimantan-Banjarmasin.

Kridalaksana, Harimurti. 2007. "Bahasa dan Linguistik". dalam Pesona Bahasa : Langkah Awal Memahami Linguistik. Jakarta: Gramedia Pustaka Utama.

Parera, Yos Daniel. 1998. Linguistik Edukational : Metode Pembelajaran $\mathrm{Ba}-$ hasa, Analisis Kontrastif Antar-bahasa, Analisis Kesalahan Berbahasa. Jakarta: Erlangga.

Pujiati, Suyata. 2007. "Status Isolek Bahasa Jawa Sala-Yogya dan Implikasinya bagi bahasa Standar". Litera Vol 1/No. 1. Hal. 1-15.

Pujiati, Suyata. 1997. " Bahasa Pertama Anak Prasekolah di Kota Yogyakarta". Penelitian, Universitas Negeri Yogyakarta.

Suhardi. 2009. "Analisis Kontrastif Bahasa Indonesia-Daerah dan Implikasinya dalam Pembelajaran Bahasa Kedua: Model Multikulturalisme dalam Pembelajaran Bahasa". Penelitian. DP2M, Dikti.

Tyron, Darrell. 1998. "Proto-Austronesian and the Mayor Austronesia Subgroups" dalam Bellwood, Peter, dkk. (1998) The Austronesian: Historical and Comparative Perspective. Canberra: ANU Printing.

Setiawati D. dan Kushatanti. 2007. "Aspek Kognitif Bahasa" dalam Pesona Bahasa: Langkah Awal Memahami Linguistik. Jakarta: Gramedia Pustaka Utama. 